\title{
Secretome of mesenchymal stem cells and its impact on Chronic Obstructive Pulmonary Disease
}

Book or Report Section

Accepted Version

Ridzuan, R., Widera, D. and Yahaya, B. H. (2019) Secretome of mesenchymal stem cells and its impact on Chronic Obstructive Pulmonary Disease. In: Pham, P. V. (ed.) Stem Cell Transplantation for Autoimmune Diseases and Inflammation. Stem Cells in Clinical Applications. Springer, pp. 139-157. ISBN 978-3-030-23420-1 doi:

https://doi.org/10.1007/978-3-030-23421-8_8 Available at http://centaur.reading.ac.uk/85665/

It is advisable to refer to the publisher's version if you intend to cite from the work. See Guidance on citing.

To link to this article DOI: http://dx.doi.org/10.1007/978-3-030-23421-8_8

Publisher: Springer

All outputs in CentAUR are protected by Intellectual Property Rights law, 
including copyright law. Copyright and IPR is retained by the creators or other copyright holders. Terms and conditions for use of this material are defined in the End User Agreement.

\section{www.reading.ac.uk/centaur}

\section{CentAUR}

Central Archive at the University of Reading

Reading's research outputs online 
Secretome of mesenchymal stem cells and its impact on Chronic Obstructive Pulmonary Disease

Ridzzaida Ridzuan, Darius Widera and Badrul Hisham Yahaya,

${ }^{1}$ Regeneraive Medicine Cluster, Advanced Medical and Dental Institute (AMDI), Universiti

Sains Malaysia, 13200 Bertam, Penang Malaysia

${ }^{3}$ Stem Cell Biology and Regenerative Medicine, School of Pharmacy, University of Reading, Reading, RG6 6AP, United Kingdom

*Corresponding author: badrul@usm.my

\begin{abstract}
Chronic obstructive pulmonary disease (COPD) is characterized by irreversible loss of lung function that stem from two mechanisms, inflammation and senescence. Crosstalk between these two mechanisms accelerate the development of COPD, thus targeting these two pathways may offer benefits in the treatment of COPD. Growing amount of evidence have shown that mesenchymal stem cells as a promising candidate for the treatment of COPD. Over the years, many studies conducted to decipher the therapeutic effect of MSC in COPD and the mechanisms involve, in the hope of utilizing these cells as new therapeutic strategy for COPD. However, the cell-based therapy by using the MSC presented with many obstacles including low engraftment at the site of injury, the risk of microvascular occlusion, unwanted differentiation, and also the risk of malignant transformation. Recently, recently researchers begin to look at the possibility of using MSC derived extracellular vesicles as an alternative to MSC. Here we review the effect of MSC and MSC derived EV in modulating inflammation, and senescence in COPD. We also review current treatment and the side effect in COPD, and senolytic drugs, a new therapeutic strategy targeting the senescent cells.
\end{abstract}


Chronic obstructive pulmonary disease (COPD) has a tremendous economic impact on healthcare and is associated with high morbidity, and high mortality rate. Global Initiative for Chronic Obstructive Lung Disease (GOLD) in 2017 reported that more than 3 million people died in 2012 accounting for $6 \%$ of total death globally. It is estimated that the prevalence and the burden of COPD to increase in the coming decade and by 2020, COPD will become the third leading cause of death worldwide. Symptoms of COPD include chronic cough, dyspnea and excessive production of sputum, while anorexia, fatigue and weight loss may present in patient with severe COPD. The diagnosis of post-bronchodilator forced expiratory volume in one second $\left(\mathrm{FEV}_{1}\right) /$ forced vital capacity $(\mathrm{FVC}) \leq 0.7$ confirms the presence of airflow limitation. The body mass index (BMI) are also useful in predicting outcomes such as survival with the values $<21 \mathrm{~kg} \mathrm{~m}^{-2}$ are associated with increased mortality (Celli et al., 2004). Cigarette smoke is the main risk factor of COPD which accounts for $80-90 \%$ of all cases. However, environmental pollution, noxious gases, genetic predisposition, pulmonary infections, and aging can also increase the risk of COPD (Churg et el.,2008).

The hallmark of COPD is chronic inflammation in the lung that leads to chronic bronchitis and emphysema. Chronic bronchitis is linked to the chronic inflammatory cells infiltration in small bronchi, leading to abnormal remodelling and mucus overproduction. Meanwhile emphysema is associated with irreversible alveolar structures that contributes to airspace enlargement without significant pulmonary fibrosis. These pathological changes lead to progressive airflow limitation however, the severity varies between patients (Grove et al., 2009). Apart from inflammation, senescence also plays an important role in the pathogenesis of COPD. Aging individuals are shown to be at higher risk of developing COPD as demonstrated by Hardie et al., (2002) in the study with $35 \%$ of healthy, never smoker, asymptomatic aged 70 years and older suffer with at least stage 1 COPD. Increase burden of COPD in elderly might be attributed to 1) Age-related changes in lung structure and function may increase the pathogenetic susceptibility to COPD and 2) Exposure to external insults render the elderly population to become vulnerable to lung injury (Fukuchi et al., 2009). Furthermore, cigarette smoke also contributed to premature lung aging by increasing the oxidative stress and DNA damage thereby inducing senescence (Hara et al., 2013). Senescence cells produced various pro inflammatory cytokines that accelerate inflammation and thus contribute to the chronic condition of COPD (Tsuji et al., 2010).

\section{Inflammation in COPD}


Inhalation of cigarette smoke or noxious gases incite the innate and adaptive immune system which in long term will cause destruction to the respiratory system. Cigarette smoke accelerates the production of reactive oxygen species (ROS) and increased the oxidative stress. This will induce cellular dysfunction or cell death and disrupts the proteinaseantiproteinase imbalance by activating proteases and inactivating antiproteinases (D'Agostino et al., 2010). Neutrophils, macrophages, and CD8 ${ }^{+} \mathrm{T}$ cells are prominent player in COPD exacerbation, however, $\mathrm{CD}^{+}{ }^{+} \mathrm{T}$ cells, regulatory $\mathrm{T}\left(\mathrm{T}_{\text {reg }}\right)$ cells, and dendritic cells (DC) may also contribute to the COPD pathogenesis. Acute inflammation takes place at the initial smoke exposure and peaked at the end of first week and chronic inflammation begin after 2 weeks of exposure. Neutrophils influx, thickening of epithelial wall and goblet hyperplasia were also observed during acute inflammation (Stevenson et al. 2007). Exposure to cigarette smoke induced epithelial cells to produce inflammatory mediators including interleukin (IL)-8, GM-CSF, IL-6, IL-1 $\beta$ (Mortaz et al., 2011). Interleukin 8 is a potent chemoattractant to neutrophils which can induce secretion of myeloperoxidase by neutrophils that can attract more inflammatory cells to sustain the inflammation (Quint et al., 2007). Subsequently, tissue macrophages begin to increase, triggering chronic inflammation. Collagen deposition, lymphocytes infiltration and macrophage aggregation were reported to be elevated (Stevenson et al. 2007). Macrophages release IL-8, IL-6, TNF- $\alpha$, monocyte chemotactic peptide-1 (MCP-1), matrix metalloprotease (MMP)-9, MMP-12, and ROS that leads to the destruction of lung parenchyma (Angelis et al., 2014). Meanwhile, type 1 cytotoxic $\mathrm{T}\left(\mathrm{Tc}^{1}\right)$ cells that predominate lung parenchyma, release granzyme $\mathrm{B}$ and perforins that may induce apoptosis to alveolar epithelial cells and thus contribute to emphysema (Majo et al., 2001). In addition, cigarette smoke exposure increased the accumulation, activation and maturation of DC in lung and in turn, DC communicate with $T$ helper $\left(T_{h}\right) 1$ cells, $T_{h} 2$ cells, and $T_{\text {reg }}$ cells to release numerous cytokines including IL-4, TNF- $\alpha$, IFN- $\gamma$, increase mucus secretion, and development of tolerance to infection (Tsoumakidou et al., 2008).

There is evidence of persistent inflammation after smoking cessation, although the mechanism has not yet been established (Lapperre et al., 2006). The number of plasma cells, and $\mathrm{CD}^{+}$and $\mathrm{CD}^{+}$lymphocytes are higher in the ex-smokers with COPD as compared to current smokers with COPD. Additionally, the number of macrophages, neutrophils, mast cells, eosinophils and $\mathrm{CD}^{+}$lymphocytes are also similar to the current smokers. Furthermore, elevation of GM-CSF, CSF-1, IL-17A, serum amyloid A after smoking cessation, have been implicated in sustained macrophages proliferation and neutrophil recruitment (Hansen et al., 2014). Persistent apoptosis in airway epithelial cells and T cells were also seen in smoking cessation group as compare to control group. Apoptosis of $\mathrm{T}$ cells 
may result in reduced immune response to external insults leading to increased risk of infection in COPD (Zuo et al., 2014). Evidence have shown that, reduced number of $T_{\text {reg }}$ cells has been implicated in autoimmunity. Regulatory $\mathrm{T}$ cells is the key player in regulation of inflammation in autoimmune disorders. Suppression of immune function occur via modulation of maturation and function of antigen presenting cells (APC), metabolic pathway disruption, killing of target cells, and anti-inflammatory cytokine secretion (Grant et al., 2015). In emphysematous lung of COPD patients, reduced level of FOXP3 mRNA, a transcription factor for $T_{\text {reg }}$ cells development, reduced number of $T_{\text {reg }}$ cells, as well as reduced IL-10 were observed, indicating autoimmune reaction in lung (Lee et al., 2007).

\section{Senescence in COPD}

The concept of cellular senescence arose from the research by Leonard Hayflick and Paul Moorhead that demonstrated normal human fibroblast cells in in vitro culture have a limited lifespan (Hayflick, 1965). When cells ceased to proliferate, it enters the state of irreversible growth arrest. Morphologically, senescent cells size is bigger than normal cells and adherent cells often exhibit a flattened shape. Senescence cells resist apoptosis and remain metabolically active, as well as excreting senescence associated secretory phenotype (SASP) (Kirkland et al., 2017). Growth arrest of senescent cells happen at $G_{0} / G_{1}$ phase of cell cycle. Senescence cells can be identified by a histochemical staining; Senescenceassociated $\beta$-galactosidase (SA- $\beta$ gal). Mammalian cells regardless age express lysosomal $\beta$-galactosidase when stained with 5-bromo-4-chloro-3-indolyl $\beta$-D-galactopyranoside (X-gal) at $\mathrm{pH} 4$. However senescence cells stained positive by $\mathrm{X}$-gal at $\mathrm{pH} 6$ caused by an increased lysosomal $\beta$-gal activity but is not demonstrated in actively proliferating cells and quiescent cells (Lee et al., 2006).

The number of senescent cells increase with age, however, senescence can also be induced in vivo and in vitro by using numerous stimulants including beryllium, bromodeoxyuridine, hydrogen peroxide, and cigarette smoke (Ross et el., 2008, Sun et al., 2015, Coates et al., 2007, Ahmad et al., 2015). These stimulants may induce reactive oxygen species (ROS), telomere attrition, DNA damage response (DDR), oncogenic-induced senescence, CDKN2A derepression, and senescence-associated secretory phenotypes (SASP) which will trigger the activation of $\mathrm{p} 53 / \mathrm{p} 21$, and $\mathrm{p} 16^{\mathrm{INK} 4 \mathrm{~A}} / \mathrm{pRb}$ signalling pathways that lead to senescence. Activation of these pathways inhibit the expression of cyclin-dependent kinases (CDKs) including CDK1, CDK2, CDK4, CDK6, Cyclin A, Cyclin E, and Cyclin D, which in turn 
suppress the phosphorylation and preventing the activation of retinoblastoma protein (Figure 1) (Campisi et al., 2007, Lujambio et al., 2016).

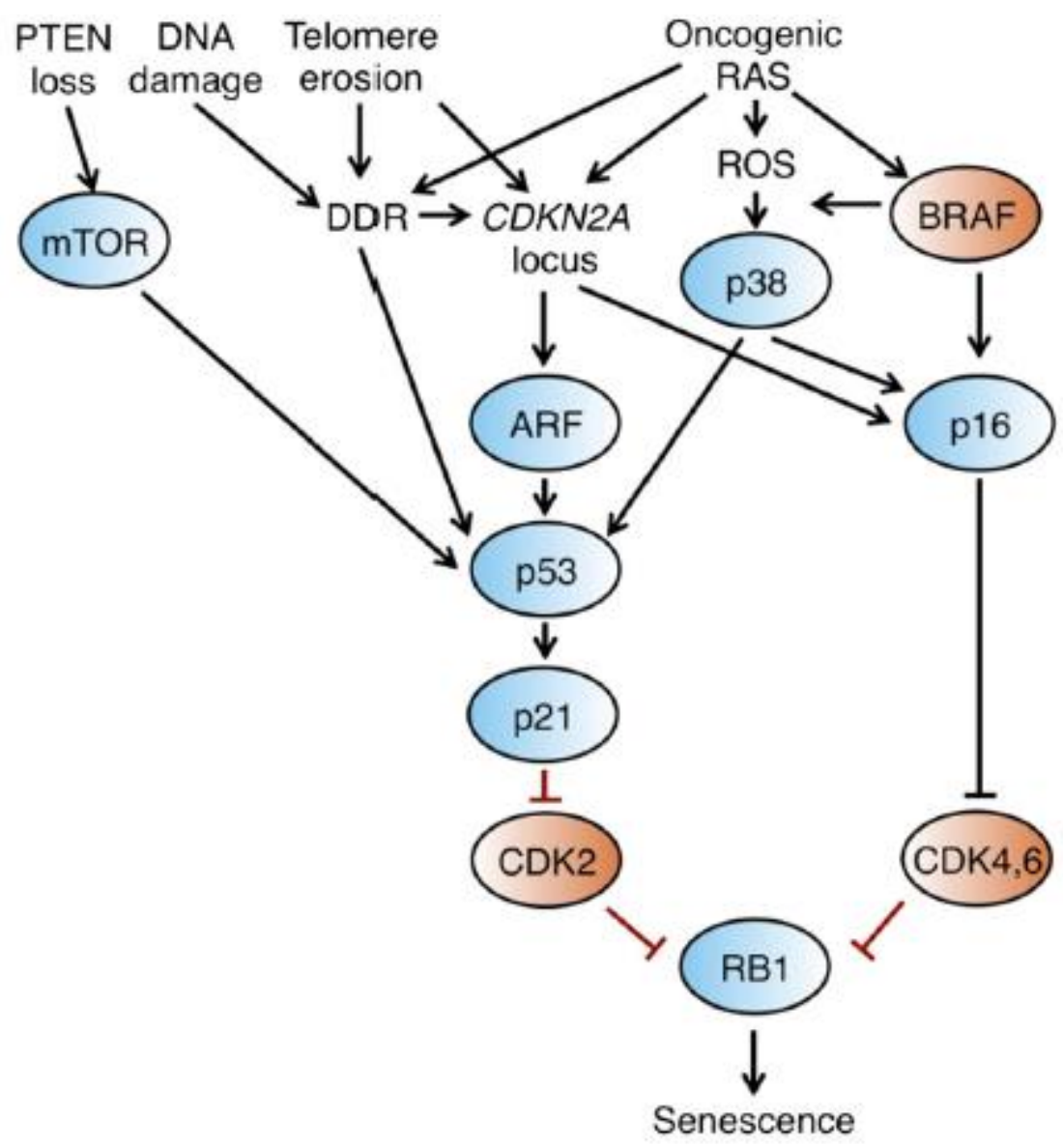

Figure 1: p53/p21 and p16/pRb signalling pathways. Multiple stress signal can trigger the activation of p53 and p16, in which both pathway may act downstream to inhibit CDKs and retinoblastoma protein (Lujambio et al., 2016).

This sophisticated mechanism is natural cell response to damaging stimuli that may cause mutation resulting in tumour formation. Senescence plays a role in tumour suppression in the early stage of tumour formation by preventing the proliferation of damaged cells. Activation of p53/p21 through DDR, arrests the human colon adenocarcinoma cells at $G_{1}$ phase of cell cycle (Waldman et al., 1995). Meanwhile, the induction of oncogenic H-Ras (V12) in primary human and rodent cells leads to $\mathrm{G}_{1}$ cell cycle arrest, increased expression of p53 and p16 which result in premature senescence (Serrano et al., 1997). Inactivation of p53 however, bypasses the onset of cellular senescence and leads to oncogenic transformation and restoring p53 function regress the tumour without affecting normal tissues (Ventura et al., 2007). Conversely, the failure of eliminating senescent cells can be damaging. The accumulation of senescent cells over time will cause damage to the tissue and result in age- 
related diseases and tumour formation. Senescent fibroblasts have been shown to stimulate the proliferation and progression of preneoplastic and neoplastic cells (Krtolica et al., 2001). This in part appear to be mediated by SASP released by senescence cells which contains numerous soluble factors including proinflammatory cytokines, chemokines, growth factors and matrix degrading proteins (Coppe et al., 2008). SASP has been shown promotes epithelial-mesenchymal transition (EMT) and stimulate the invasion of tumour cells by the action of two secreted cytokine; interleukin (IL) -6 and IL-8 (Coppe et al., 2008).

Senescence play a significant role in the pathogenesis of COPD by altering the cellular functions and contribute to the chronic inflammation. In aging lung, alveolar structures are altered, reduced respiratory muscle strength, modification of extracellular matrix composition, vascular remodelling, reduced lung function, and impaired capacity of gas exchange. This in part, might explain why aging population has higher risk in developing COPD (Karrasch et al., 2008). In addition, long term exposure to cigarette smoke will accelerate telomere shortening in type II alveolar epithelial cells (AEC type II) that will cause senescence in type II alveolar epithelial cells. As a result, senescence AEC type II may contribute to insufficient regeneration of alveolar cells which in turn leads to emphysema (Tsuji et al., 2006). Cigarette smoke disrupt many proteins and enzymes level which may accelerate cellular senescence in lung. Brain type-creatine kinase (CKB) that is involve in energy homeostasis of cells, has been shown to be associated with acceleration of bronchial epithelial cells senescence. Depletion of CKB induced p21 expression, G2/M cell cycle arrest, accumulation of protein involves in mitosis, Cyclin B1, that cause cells to become senescent as well as increased level of IL-8 (Hara et al., 2012). In addition, exposure of lung fibroblast and small airway epithelial cells (SAEC) to cigarette smoke extract also lead to interaction of p53 and E3 ubiquitin ligase (Parkin). This interaction will reduce Parkin translocation to damaged mitochondria, hence impairing damaged mitochondria clearance, thus accumulation of senescent cells (Ahmad et al., 2015). In mice model exposed to cigarette smoke for 6 months, significant decreased of sirtuin 1 (SIRT1) was observed. Sirtuin 1 is NAD+dependent protein/histone deacetylase that involves in wide range of processes including aging and inflammation (Rajendrasozhan et al., 2008). Sirtuin 1 has been shown to interact with FOXO3 and p21 in mitigating senescence in emphysematous lung. However, the absence of FOXO3 and p21 deficiency, SIRT1 failed to exert its effect, thus accelerating senescence and emphysema (Yao et al., 2012). 


\section{Interaction between inflammation and senescence}

Chronic inflammation has been implicated in senescence and accelerate ageing. Many agerelated diseases such as Alzheimer's disease, diabetes type-2, atherosclerosis, and Parkinson's disease presented with chronic, low-grade inflammation as an important mechanism responsible for the disease progression (Ikeno et al., 2011). Various proinflammatory mediators such as IL-6, TNF- $\alpha$, CXCR-2, IFN- - , and TGF- $\beta$ collectively aggravate the inflammation and senescence. NF-K $\beta$ as the master regulator of many gene, cytokines, adhesion molecules, enzymes, many of which related to inflammation as well as apoptosis (Serasanambati et al., 2016), may also play a role in inducing senescence. In addition, chronic inflammation also exhibited increased expression of p21 and p16, and downregulation of anti-inflammatory cytokines, IL-4 and IL-10 (Jurk et al., 2014). Prolonged treatment of IFN- $y$ in HUVEC enhanced oxidative stress, and arrested cells in G0/G1 phase of cell cycle thus inducing cellular senescence through p53/p21 pathway, and not p16 (Kim et al., 2009). Meanwhile, tumor necrosis factor- $\alpha$ also increase number of senescent endothelial cells, induced p21 expression, and endothelial dysfunction (Yamagata et al.,2016). However, TNF and IFN-y alone unable to induced senescence in murine breast cancer. Combination of TNF and IFN-y are needed in order to successfully halt the cancer

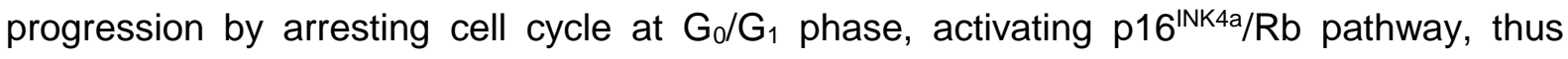
inducing senescence (Braumuller et a.,2013).

Senescence has also been shown to contribute in inflammation through the production of SASP. mRNA level of SASP components such as IL-6, IL-8, MCP-1, IL-1ß, MMP-3, MMP12 , and TNF- $\alpha$ increased significantly in senescent cells (Xu et al., 2015). In the lung of aging mice, cDNA array analysis demonstrated that 8 genes including CD20, CXCR-3, CD72, IL-8RB, and C-Fgr that are related to inflammation were upregulated. Increased number of CD8 cells, CD4 cells, macrophages, and B cells were also been observed (Aoshiba et al., 2007). Cigarette smoke induced cellular senescence in type II alveolar epithelial cells by increasing the expression of $\mathrm{P} 16^{\mathrm{INK} 4 a}$ and phosphorylated NF-KB, along with pro-inflammatory cytokines IL-6, IL-8, and TNF- $\alpha$ (Tsuji et al., 2010). Senescence pulmonary vascular endothelial cells exhibited increase p16 and p21 mRNA expression, shorter telomeres, reduced telomerase activity, and also excreted increase level of IL-6, IL-8, MCP-1, Hu-GRO, and soluble ICAM-1. Enhanced secretion of soluble ICAM-1 and MCP-1 led to increase monocyte adherence and migration which in turn will aggravate inflammation (Amsellem et al., 2011). 


\section{Current treatment for COPD}

The main objectives of COPD management are focusing on reducing symptoms and exacerbation, preserving lung function decline, reducing mortality while increasing exercise capacity and improving health status. Smoking cessation remains to be an effective intervention for COPD as it results in improved $\mathrm{FEV}_{1}$, reduction in hospital admission, lower prevalence of cough, sputum production, wheezing and shortness of breath (Gotfredsen et al., 2002, Kanner et al., 1999). A wide range of pharmacotherapeutic drugs are also available for the treatment of COPD, such as bronchodilators, muscarinic antagonist, and corticosteroids, however, the administration of these drugs is often associated with adverse effect.

Bronchodilators is a type of drugs that promotes airway smooth muscle relaxation and improved lung emptying during tidal breathing. Common bronchodilators include anticholinergic drugs, beta 2 agonists and methylxanthine which can be administered orally,

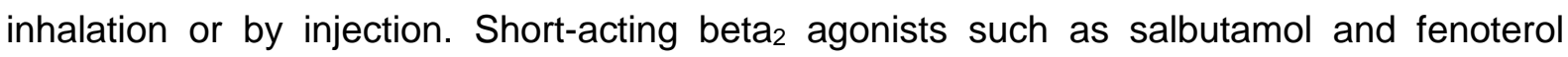
provides a quick relief from symptoms. On the other hand, long-acting beta ${ }_{2}$ agonists such as salmeterol and formoterol help to control persistent symptoms but do not provide quick relief (Ejiofor et al., 2013). Theophylline, a type of methylxanthine is a long-acting bronchodilator used to treat airway disease. However, to achieve significant

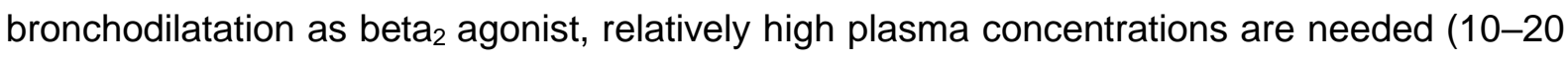
$\mathrm{mg} / \mathrm{l})$ (Barnes, 2006).

Muscarinic antagonist exerts its action by blocking the bronchoconstrictor effects of acetylcholine on M3 muscarinic receptors. Ipratropium bromide, the most common shortacting muscarinic agonist (SAMA) exerts its action within minutes and last for approximately 4 hours. (Ejiofor et al., 2013). According to the Lung Health Study, regular ipratropium use has no effect on the rate of decline of lung function over time in mild to moderate COPD. Meanwhile, long-acting muscarinic antagonists like tiotropium and aclidinium bromide have a longer duration of action of over 24 hours due to prolong binding to the M3 muscarinic receptor and faster dissociation from M2 muscarinic receptor. On the other hand, inhaled corticosteroids (ICS) are prescribed in high doses for COPD, however beneficial effect in patient is controversial as it does not effective in slowing the reduction in lung function. Combination of ICS and beta $_{2}$ agonist is effective in improving lung function and reducing exacerbation in patient with moderate to severe COPD as compared to single component (Nannini et al., 2007). In a double-blind cross over study, Culpitt and colleagues (1998) examined the effect of $500 \mu \mathrm{g}$ fluticasone propionate which given twice a day for 4 weeks. There are no changes in sputum supernatant elastase activity, anti-proteases secretory 
leukoprotease inhibitor (SLPI), matrix metalloproteinase (MMP)-1, MMP-9 and tissue inhibitor of metalloproteinase (TIMP)-1, suggesting that ICS has no benefit in reducing inflammation.

\section{Side effect of COPD drugs}

Generally, bronchodilators are well tolerated. However, several studies reported multiple adverse effect on patient prescribed with bronchodilators. Chest pain, headache, and syncope were experienced by patient prescribed with formoterol (Thomson et al., 1998) and cardiac rhythmic disturbance was reported in patient prescribed with terbutaline (Lipworth et

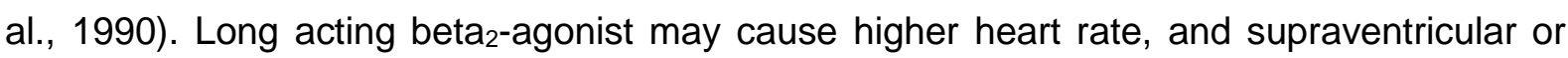
ventricular premature in COPD patient with pre-existing arrhythmia and hypoxemia (Cazzola et al., 1998). Administration of theophylline is associated with headache, abdominal discomfort, nausea and vomiting, and restlessness, increased acid secretion, gastroesophageal reflux, and diuresis. Convulsions, cardiac arrhythmias, and death may occur at high concentration. These side effects are due to the increase of plasma concentration (Barnes, 2005).

Dry mouth is the most common side effect of muscarinic agonist. A 4-year trial of tiotropium in COPD patient reported adverse effect including pneumonia, dyspnea as well as dry mouth and constipation (Tashkin et al., 2008). A randomized controlled trial on ipratropium and tiotropium suggested an increased risk of myocardial infarction, cardiovascular death, and stroke (Singh et al., 2008), while another study reported no significant effect of triotropium on cardiovascular mortality, myocardial infarction, and respiratory mortality, although dyspnea, dry mouth and upper respiratory tract infection were observed (Kesten et al., 2006). A comparison study between indacaterol and triotropium showed that both drugs produced similar side effects such as cough, nasopharyngitis, COPD exacerbation, headache, influenza, and bronchitis (Dunn et al., 2010). A 24-weeks, randomized, placebo-controlled study demonstrated that aclidinium bromide is associated with multiple adverse effect including cough, headache, nasopharyngitis, urinary tract infection, diarrhea, muscle spasm, dyspnea, and nausea (D D'urzo et al., 2014). Evidence suggested that there is increase of fractures in COPD patient when treated with ICS (Loke et al., 2011). The use of ICS is also associated with increased risk of pneumonia; however, the risk declines gradually after stopping the ICS use (Suissa et al., 2013). A study using fluticasone furoate depicted increase risk of pneumonia, fractures, and nasopharyngitis in fluticasone furoate only group, 
and fluticasone furoate/vilanterol group (Dransfield et al., 2013). Skin bruising, oropharyngeal candidiasis and throat irritation were also prominent in COPD patient prescribed with high dose of ICS (Pauwels et al., 1999).

\section{Senolytic drugs as a new therapy in eliminating senescent cells}

Recently, research begins to look at the possibility of developing new pharmacological strategies that are able to selectively eliminate senescent cells without harming healthy quiescent and proliferating cells. This strategy is thought to be beneficial as senescent cells have been implicated in the development of chronic diseases and tumour formation. Since senescent cells resist apoptosis, a study was conducted to analyse pro-survival markers in senescent cells including ephrin ligands (EFNB1 and EFNB3), PI3KCD, p21, Bcl-2, PAI-1, and PAI-2. Administration of drugs or silencing these markers, killed senescent cells without harming proliferating cells and quiescent cells (Zhu et al., 2015). Since then, more studies have been done to identify drugs that can potentially be used in killing senescent cells including dasatinib, quercetin, navitoclax, and 17-DMAG.

Zhu and colleagues (2015) found out that dasatinib and quercetin were able to reduce senescent cells number. Dasatinib and quercetin were tested in experimental lung fibrosis model, in which combination of dasatinib and quercetin reduced senescent cells number, decreased level of $\mathrm{p} 16$, reduced expression of SASP components such as IL-6, MMP12, SPP1, serpine 1, collagen 1a1, collagen 5a3, fibronectin, increased level of caspase 3 , and increased epithelial cell marker E-cadherin, AECII markers SFTPC and SFTPA (Lehmann et al., 2017). Fuhrmann-Stroissnigg and colleagues (2017) recently identified HSP90 inhibitor, 17-DMAG as a potential new senolytic drug in which the treatment of senescent MEF with 17-DMAG selectively induced apoptosis in these cells, as well as murine MSCs, IMR90, and human lung fibroblast cells (WI38). 17-DMAG also reduced the expression of p16 ${ }^{\text {INK4a }}$, SASP component IL-6, DNA damage marker $\mathrm{YH} 2 \mathrm{AX}$, and reduced $\mathrm{p}-\mathrm{AKT}$ level. Administration of 17-DMAG in progeroid mouse model, decreased age-related symptoms including, tremor, ataxia, gait disorder, dystonia, and kyphosis (Fuhrmann-Stroissnigg et al., 2017). Navitoclax and TW-37, member of Bcl-2 family inhibitor have been tested in in vitro setting by using human umbilical vein epithelial cells (HUVEC), human lung fibroblast (IMR90), murine embryonic fibroblast (MEF) and preadipocytes. Navitoclax induced apoptosis in HUVEC, IMR90, MEF, but not preadipocytes. TW-37 however, has very little senolytic effect over these cells, which may be due to different in level of targets between navitoclax and TW-37 (Zhu et al., 2016). In addition, dasatinib is more effective in eliminating senescent cells in preadipocyte and less effective in senescent HUVEC. Meanwhile quercetin kills senescent 
HUVEC but not effective against senescent preadipocyte (Zhu et al., 2015). A more recent study demonstrated that, BCL-XL inhibitors, A1331852 and A1155463 induced apoptosis in senescent HUVEC and IMR90, but not senescent preadipocyte (Zhu et al., 2017). In addition, another HSP90 inhibitor, ganetespib reduced the viability of senescent HUVEC, but not preadipocyte (Fuhrmann-Stroissnigg et al., 2017). This indicates that senolytic drugs is cell specific, targeting different proteins and pathways. However, many of these drugs have been used in treating other diseases such as leukemia, lung cancer, and ovarian cancer, which can cause side effects (Aguilera et al., 2009, Niu et al., 2009, Rudin et al., 2012). It is not clear however, if these drugs can be used in the treatment of COPD.

\section{Mesenchymal Stem Cells}

Mesenchymal stem cells are multipotent adult stem cells with fibroblast-like morphology that can be found mainly in the bone marrow. International Society of Cellular Therapy has proposed three minimal criteria to define mesenchymal stem cells (MSCs); I) MSC is plastic adherent under standard culture condition. II) MSC should expressed CD73, CD90 and CD29 and III) MSC are capable of differentiating into osteocytes, chondrocytes, and adipocytes (Wuchter et al., 2013). Mesenchymal stem cells possess the ability to modulate innate and adaptive immune systems mediated by cell-to-cell contact and the secretion of paracrine factors. Interaction of MSC with immune cells produced myriad of effects such as enhanced differentiation of $B$ lymphocytes into plasma cells, impaired function of dendritic cells, inhibition of $\mathrm{T}$ lymphocytes proliferation, as well as enhanced respiratory burst activity of macrophages (Vasandan et al., 2016, Bonnaure et al., 2016, Tabera et al., 2008, Jarvinen et al., 2008). In addition, MSC are also capable of homing to the site of injury, and the lack of Major Histocompatibility Complex class II (MHCII) expression and low expression of $\mathrm{MHCl}$ makes MSC hypoimmunogenic and thus escape immune recognition (Pittenger et al., 1999, Zhao et al., 2016).

In the past decade, studies have been conducted in preclinical and clinical settings for the treatment of various disease including GVHD, diabetes, neurological disorders, heart diseases, cancers, and lung diseases. Whilst the results have been encouraging, there are still major challenges to overcome before stem cell-based therapy can be translated into clinical settings. One of the major concern of with cell-based therapy using MSC is the risk of malignant transformation. Prolonged culture of MSC have shown to spontaneously transformed itself in vitro and when transplanted in mice model, the cells formed fibrosarcoma with p53 mutation ( $\mathrm{Li}$ et al., 2007). Another study has also reported unwanted differentiation in transplanted MSC in mice model of myocardial infarction which resulted in 
calcification and bone formation at the injury site (Breitbach et al., 2007). These unregulated growths are thought to occur due to genetic and epigenetic changes during handling and cultivation of stem cells (Mousavinejad et al., 2016). In addition, the engraftment of MSC in the injury area appeared to be low is insufficient to account for therapeutic response, suggesting paracrine-mediated mechanism of MSC (van Haaften et al., 2009). Furthermore, study demonstrated that administration of MSC resulted in immediate death of the animal due to pulmonary embolism associated with large size of MSC or cellular clumping (Antunes et al., 2014).

\section{Mesenchymal stem cells in the treatment of COPD}

Research on MSC as a new therapeutic regiment for COPD is currently focusing more on ameliorating the inflammation. The effect of MSC in mitigating the inflammation have been extensively studied in preclinical settings and tested in clinical trial all over the world. Attenuation of inflammation and increase secretion of cytokines involve in tissue repair by MSC significantly improved lung function, and stimulate the lung tissue regeneration (Liu et al., 2016). Besides ameliorating inflammation, MSC have a remarkable regenerative capability to differentiate into functional type II alveolar epithelial cells with the ability to express surfactant-related genes and proteins (Cerrada et al., 2014). Destruction of alveolar wall in elastase induce emphysema leads to reduction in pressure of arterial oxygen $\left(\mathrm{PaO}_{2}\right)$ and alveolar-arterial oxygen gradient $\left(\mathrm{A}-\mathrm{aDO}_{2}\right)$ which will impair the pulmonary function. Regeneration of alveolar wall by MSC restore the pulmonary function by increase $\mathrm{PaO}_{2}$ and $\mathrm{A}-\mathrm{aDO}_{2}$ level, and decrease the mean linear intercept (Furuya et al., 2012).

Although MSC have shown a tremendous benefit in preclinical studies, a recent phase II, randomized, double-blind, placebo-controlled study was conducted on 62 moderate-tosevere COPD patients receiving intravenous allogeneic MSC appeared to be safe with no significant adverse effect, and no increase in exacerbation. However, there is no significant difference in pulmonary function test and quality of life, although there is decreased in circulating C-reactive protein which indicate there is anti-inflammatory effect of MSC on systemic inflammation (Weiss et al.,2013). However, a more recent phase I study to evaluate the safety of MSC administration after lung volume reduction surgery for severe emphysema demonstrated an increased in FEV1 after 12 months follow up, and a 3-fold increase of CD31 in alveolar septa which indicates responsiveness of microvascular endothelial cells to MSC treatment (Stolk et al., 2016).

Although MSC are capable of attenuating the inflammation in COPD, it is unknown whether MSC can regulate the senescence in COPD. Recently, an in vitro study was conducted to 
determine the effect of MSC in hypoxia/reoxygenation-induced premature senescence in cardiomyocyte. Co-culture of MSC have been shown to reduce the number of senescent cardiomyocytes and decreased expression of p53 and p21. However, MSC do not have any effect of p16, suggesting that MSC exert its effect via p53/p21 Cip1/Waf1 pathway but not p16 INK4a/Rb pathway (Cai et al., 2012). This encouraging evidence led to in vivo study by the same group using natural aging rat model. Four months old and 20 months old Sprague Dawley (SD) rat was used as young and natural aging model respectively. Consistent with previous result, transplantation of MSC inhibit oxidative stress, as well as reduced the expression of senescence markers p53 and p21, but not p16. Mesenchymal stem cells also significantly decreased senescent cells number and normalized endogenous anti-oxidant activity. Attenuation of senescence effect on aging heart improved cardiac function, cardiac hypertrophy and fibrosis as evident in MSCs treated group (Zhang et al., 2015). In addition, another study has been conducted in premature aging model of Bmi-1 deficiency. Mesenchymal stem cells transplantation in Bmi-1 deficiency mice, inhibits apoptosis while migrating into multiple organs, proliferate, and differentiate into various cells, thus promoting growth and delay senescence. Mesenchymal stem cells also downregulate senescence markers p16, p19, and p27 expression as well as Wnt16, prolonged the survival rate, increased body weight, increased proliferation of thymocyte and renal cells, ameliorate skeletal growth and development retardation, improved dysmaturity of $\mathrm{T}$ lymphocytes, decreased intracellular ROS level and hydrogen peroxide level, and increased level of antioxidant, superoxide dismutase and catalase (Xie et al., 2015).

\section{Therapeutic application of mesenchymal stem cells derived extracellular vesicles in lung diseases}

Due to the limitation faced in cell-based therapy, much focus has been diverted into the possibility of using extracellular vesicles (EV) released by MSC as a potential new therapeutic regiment for various diseases. Extracellular vesicles are small membrane vesicles released by various types of cells and also can be found in body fluids such as milk, saliva, urine, amniotic fluid and cerebral spinal fluid that is important for cell-to-cell communication. The size of EV range from $40-1000 \mathrm{~nm}$ and can be sedimented by centrifugation at 100,000 g. The most prominent extracellular vesicles are exosome and microvesicles that contain various types of proteins, lipids, messenger ribonucleic acid (mRNA) and micro RNA (miRNA). These EV participate in many physiological and pathological processes including inflammation, cancer progression, immune responses, and angiogenesis (Ludwig et. al., 2011, Yu et. al., 2014). Extracellular vesicles are naturally 
stable due to its lipid membrane similar to the cells itself can easily be taken up by the cells. MSC derived EV also possess no risk of pulmonary embolism due to its small size, and do not contain nuclei, therefore, EV do not replicate, thus avoiding the risk of forming teratoma and unwanted differentiation as compared to MSC (Chen et al., 2011).

To date, there is no report on the effect of MSC derived EV on inflammation and senescence in COPD, however, understanding how MSC derived EV exerts its function in other diseases may give an insight on the mechanism involved. Administration of MSC derived EV inhibited the vascular remodelling and hypoxic pulmonary hypertension model through the inhibition of transcription factor STAT-3, reduction of pro-inflammatory mediators MCP-1, IL-6, FIZZ1/HIMF, inhibition of pulmonary artery smooth muscle cells, and suppression of miR-17 (Lee et al., 2012). In influenza-induced lung injury, MSC derived EV inhibited the influenza replication in lung epithelial cells, reduced the level of TNF- $\alpha$, CXCL-10, and increased the level of pro inflammatory cytokine IL-10, as well as inhibited the apoptosis of lung epithelial cells (Khatri et al., 2018). Similar findings demonstrated the ability of MSC derived EV to ameliorate pulmonary oedema and lung protein permeability in acute lung injury through reduction of total white blood cells count, neutrophils, and MIP-2, as well as increasing the $\mathrm{IL}-10$. This therapeutic effect by MSC derived EV is thought to occur due to the transfer of EV's content into the cells. MSC derived EV contain mRNA for keratinocyte growth factor (KGF) that involve in alveolar fluid clearance and blocking the KGF mRNA expression abrogated the effect of MSC derived EV. In addition, MSC derived EV are also able to provide therapeutic effect, and home to the site of injury following intravenous injection similar to MSC. (Zhu et al., 2014). Notably, MSC derived EV have been reported to induce lung adenocarcinoma cells growth by transferring miRNA-410 to the cells, resulted in increased proliferation rate, and lower apoptosis rate of the cells (Dong et al., 2018). However, conflicting result was reported in which MSC are inhibiting the lung tumour formation induced by chemical carcinogen (Liu et al., 2017). This contradicting effect in part may be due to the different source of MSC and different cargo content of EV. Del Fattore and colleagues (2015) demonstrated that bone marrow and umbilical cord MSC derived EV reduced the proliferation and increase apoptosis rate of glioblastoma cells, while adipose tissue MSC derived EV does not produce any effect, suggesting the role of tissue origin of MSC in mediating MSC derived EV effect (Del Fattore et al., 2015). In addition, a study conducted by Tofino-Vian et al., in 2017 to study the effect of MSC derived EV on osteoarthritic osteoblast induced by IL-1 $\beta$ showing a promising result in which MSC derived $E V$ are shown to reduced the SA- $\beta$ galactosidase activity and the accumulation of $\mathrm{YH} 2 \mathrm{AX}$ foci, as well as downregulated the mitochondrial membrane changes and oxidative stress. 


\section{Conclusion}

Considering the limitations of MSC, MSC derived EV could be a new therapeutic tool for the treatment of COPD. Although MSC derived EV have shown a tremendous effect in attenuating the inflammation and senescence in other model diseases, the effect of MSC derived EV on senescence in COPD is currently unknown. Thus, it is important to understand how MSC derived EV may exert its effect on inflammation and senescence in COPD. Long-term study should also be conducted to determine the safety and side effect that may occur with the administration of MSC derived EV. More studies should be done to standardize the culture condition of MSC, and methods of isolation of MSC derived EV as to maximize production of EV while maintaining normal phenotype. Optimal dosage, route of administration, and biodistribution of MSC derived EV should also be addressed before it can be translated into clinical settings.

\section{Financial \& competing interests disclosure}

Badrul Hisham Yahaya is supported by grant from Universiti Sains Malaysia (USM) Research University Grant (1001/CIPPT/8012203). The authors declare no other financial involvement with any organization or entity with financial interest and/or conflict with matters discussed in the manuscript apart from those disclosed.

\section{Reference}

Acosta, J.C., O'Loghlen, A., Banito, A., Guijarro, M.V., Augert, A., Raguz, S., Fumagalli, M., Da Costa, M., Brown, C., Popov, N. and Takatsu, Y., 2008. Chemokine signaling via the CXCR2 receptor reinforces senescence. Cell, 133(6), pp.1006-1018.

Aguilera, D.G. and Tsimberidou, A.M., 2009. Dasatinib in chronic myeloid leukemia: a review. Therapeutics and clinical risk management, 5, p.281.

Ahmad, T., Sundar, I.K., Lerner, C.A., Gerloff, J., Tormos, A.M., Yao, H. and Rahman, I., 2015. Impaired mitophagy leads to cigarette smoke stress-induced cellular senescence: implications for chronic obstructive pulmonary disease. The FASEB Journal, 29(7), pp.29122929.

Akram, K.M., Samad, S., Spiteri, M.A. and Forsyth, N.R., 2013. Mesenchymal stem cells promote alveolar epithelial cell wound repair in vitro through distinct migratory and paracrine mechanisms. Respiratory research, 14(1), p.9.

Amsellem, V., Gary-Bobo, G., Marcos, E., Maitre, B., Chaar, V., Validire, P., Stern, J.B., Noureddine, H., Sapin, E., Rideau, D. and Hue, S., 2011. Telomere dysfunction causes sustained inflammation in chronic obstructive pulmonary disease. American journal of respiratory and critical care medicine, 184(12), pp.1358-1366.

Angelis, N., Porpodis, K., Zarogoulidis, P., Spyratos, D., Kioumis, I., Papaiwannou, A., Pitsiou, G., Tsakiridis, K., Mpakas, A., Arikas, S. and Tsiouda, T., 2014. Airway inflammation in chronic obstructive pulmonary disease. Journal of thoracic disease, 6(Suppl 1), p.S167. 
Antunes, M.A., Abreu, S.C., Cruz, F.F., Teixeira, A.C., Lopes-Pacheco, M., Bandeira, E., Olsen, P.C., Diaz, B.L., Takyia, C.M., Freitas, I.P. and Rocha, N.N., 2014. Effects of different mesenchymal stromal cell sources and delivery routes in experimental emphysema. Respiratory research, 15(1), p.118.

Aoshiba, K. and Nagai, A., 2007. Chronic lung inflammation in aging mice. FEBS letters, 581(81), pp.3512-3516

Ardestani, M.E. and Zaerin, O., 2015. Role of serum interleukin 6, albumin and C-reactive protein in COPD patients. Tanaffos, 14(2), p.134.

Aslam, M., Baveja, R., Liang, O.D., Fernandez-Gonzalez, A., Lee, C., Mitsialis, S.A. and Kourembanas, S., 2009. Bone marrow stromal cells attenuate lung injury in a murine model of neonatal chronic lung disease. American journal of respiratory and critical care medicine, 180(11), pp.1122-1130.

Baghaban Eslaminejad Mohamadreza, M.S., and M. Ebrahimi. 2011. Mesenchymal stem cells derived from rat epicardial versus epididymal adipose tissue. Iranian Journal of Basic Medical Sciences.

Barnes, Peter J. "Theophylline in chronic obstructive pulmonary disease: new horizons." Proceedings of the American Thoracic Society 2.4 (2005): 334-339.

Barnes, P. J. "Theophylline for COPD." (2006): 742-743.

Barr, R. Graham, Brian H. Rowe, and Carlos A. Camargo. "Methylxanthines for exacerbations of chronic obstructive pulmonary disease: meta-analysis of randomised trials." Bmj 327.7416 (2003): 643.

Braumüller, H., Wieder, T., Brenner, E., Aßmann, S., Hahn, M., Alkhaled, M., Schilbach, K., Essmann, F., Kneilling, M., Griessinger, C. and Ranta, F., 2013. T-helper-1-cell cytokines drive cancer into senescence. Nature, 494(7437), p.361.

Braza, F., Dirou, S., Forest, V., Sauzeau, V., Hassoun, D., Chesné, J., Cheminant-Muller, M.A., Sagan, C., Magnan, A. and Lemarchand, P., 2016. Mesenchymal stem cells induce suppressive macrophages through phagocytosis in a mouse model of asthma. Stem Cells, 34(7), pp.1836-1845.

Breitbach, M., Bostani, T., Roell, W., Xia, Y., Dewald, O., Nygren, J.M., Fries, J.W., Tiemann, K., Bohlen, H., Hescheler, J. and Welz, A., 2007. Potential risks of bone marrow cell transplantation into infarcted hearts. Blood, 110(4), pp.1362-1369.

Buist, A.S., 2003. Similarities and differences between asthma and chronic obstructive pulmonary disease: treatment and early outcomes. European respiratory journal, 21(39 suppl), pp.30s-35s.

Butt, Y., Kurdowska, A. and Allen, T.C., 2016. Acute lung injury: a clinical and molecular review. Archives of Pathology and Laboratory Medicine, 140(4), pp.345-350.

Cai, Benzhi, et al. "Bone marrow-derived mesenchymal stem cells protected rat cardiomyocytes from premature senescence." International journal of cardiology 154.2 (2012): 180-182.

Cai, M., Shen, R., Song, L., Lu, M., Wang, J., Zhao, S., Tang, Y., Meng, X., Li, Z. and He, Z.X., 2016. Bone marrow mesenchymal stem cells (BM-MSCs) improve heart function in swine myocardial infarction model through paracrine effects. Scientific reports, 6. 
Campisi, J. and di Fagagna, F.D.A., 2007. Cellular senescence: when bad things happen to good cells. Nature reviews. Molecular cell biology, 8(9), p.729.

Carbone, A., Castellani, S., Favia, M., Diana, A., Paracchini, V., Di Gioia, S., Seia, M., Casavola, V., Colombo, C. and Conese, M., 2014. Correction of defective CFTR/ENaC function and tightness of cystic fibrosis airway epithelium by amniotic mesenchymal stromal (stem) cells. Journal of cellular and molecular medicine, 18(8), pp.1631-1643.

Cazzola, M., Imperatore, F., Salzillo, A., Di Perna, F., Calderaro, F., Imperatore, A. and Matera, M.G., 1998. Cardiac effects of formoterol and salmeterol in patients suffering from COPD with preexisting cardiac arrhythmias and hypoxemia. Chest, 114(2), pp.411-415.

Celli, Bartolome R., et al. "Standards for the diagnosis and treatment of patients with COPD: a summary of the ATS/ERS position paper." European Respiratory Journal 23.6 (2004): 932946.

Cerrada, A., de la Torre, P., Grande, J., Haller, T., Flores, A.I. and Pérez-Gil, J., 2014. Human decidua-derived mesenchymal stem cells differentiate into functional alveolar type IIlike cells that synthesize and secrete pulmonary surfactant complexes. PloS one, 9(10), p.e110195.

Chang, Y.S., Ahn, S.Y., Yoo, H.S., Sung, S.I., Choi, S.J., Oh, W.I. and Park, W.S., 2014. Mesenchymal stem cells for bronchopulmonary dysplasia: phase 1 dose-escalation clinical trial. The Journal of pediatrics, 164(5), pp.966-972.

Chen, D., Liu, S., Ma, H., Liang, X., Ma, H., Yan, X., Yang, B., Wei, J. and Liu, X., 2015. Paracrine factors from adipose-mesenchymal stem cells enhance metastatic capacity through Wnt signaling pathway in a colon cancer cell co-culture model. Cancer cell international, 15(1), p.42.

Chen, T.S., Arslan, F., Yin, Y., Tan, S.S., Lai, R.C., Choo, A.B.H., Padmanabhan, J., Lee, C.N., de Kleijn, D.P. and Lim, S.K., 2011. Enabling a robust scalable manufacturing process for therapeutic exosomes through oncogenic immortalization of human ESC-derived MSCs. Journal of translational medicine, 9(1), p.47.

Churg, Andrew, Manuel Cosio, and Joanne L. Wright. "Mechanisms of cigarette smokeinduced COPD: insights from animal models." American Journal of Physiology-Lung Cellular and Molecular Physiology 294.4 (2008): L612-L631.

Confalonieri, M., Mainardi, E., Della Porta, R., Bernorio, S., Gandola, L., Beghè, B. and Spanevello, A., 1998. Inhaled corticosteroids reduce neutrophilic bronchial inflammation in patients with chronic obstructive pulmonary disease. Thorax, 53(7), pp.583-585.

Coates, S.S., Lehnert, B.E., Sharma, S., Kindell, S.M. and Gary, R.K., 2007. Beryllium induces premature senescence in human fibroblasts. Journal of Pharmacology and Experimental Therapeutics, 322(1), pp.70-79.

Coppé, J.P., Patil, C.K., Rodier, F., Sun, Y., Muñoz, D.P., Goldstein, J., Nelson, P.S., Desprez, P.Y. and Campisi, J., 2008. Senescence-associated secretory phenotypes reveal cell-nonautonomous functions of oncogenic RAS and the p53 tumor suppressor. PLoS Biol, 6(12), p.e301.

Cui, R., Rekasi, H., Hepner-Schefczyk, M., Fessmann, K., Petri, R.M., Bruderek, K., Brandau, S., Jäger, M. and Flohé, S.B., 2016. Human mesenchymal stromal/stem cells acquire immunostimulatory capacity upon cross-talk with natural killer cells and might improve the NK cell function of immunocompromised patients. Stem cell research \& therapy, 7(1), p.88. 
Culpitt, S.V., Nightingale, J.A. and Barnes, P.J., 1999, March. Effect of fluticasone propionate on induced sputum matrix metalloproteinases and tissue inhibitors of metalloproteinases in patients with COPD. In AMERICAN JOURNAL OF RESPIRATORY AND CRITICAL CARE MEDICINE (Vol. 159, No. 3, pp. A812-A812). 1740 BROADWAY, NEW YORK, NY 10019 USA: AMER LUNG ASSOC.

D'Agostino, B., Sullo, N., Siniscalco, D., De Angelis, A., \& Rossi, F. (2010). Mesenchymal stem cell therapy for the treatment of chronic obstructive pulmonary disease. Expert opinion on biological therapy, 10(5), 681-687

D D'Urzo, A., Rennard, S.I., Kerwin, E.M., Mergel, V., Leselbaum, A.R. and Caracta, C.F., 2014. Efficacy and safety of fixed-dose combinations of aclidinium bromide/formoterol fumarate: the 24-week, randomized, placebo-controlled AUGMENT COPD study. Respiratory research, 15(1), p.123.

de Oliveira, R.M., 2006. Klotho RNAi induces premature senescence of human cells via a p53/p21 dependent pathway. FEBS letters, 580(24), pp.5753-5758.

Del Fattore, A., Luciano, R., Saracino, R., Battafarano, G., Rizzo, C., Pascucci, L., Alessandri, G., Pessina, A., Perrotta, A., Fierabracci, A. and Muraca, M., 2015. Differential effects of extracellular vesicles secreted by mesenchymal stem cells from different sources on glioblastoma cells. Expert opinion on biological therapy, 15(4), pp.495-504.

Demaria, M., Ohtani, N., Youssef, S.A., Rodier, F., Toussaint, W., Mitchell, J.R., Laberge, R.M., Vijg, J., Van Steeg, H., Dollé, M.E. and Hoeijmakers, J.H., 2014. An essential role for senescent cells in optimal wound healing through secretion of PDGF-AA. Developmental cell, 31(6), pp.722-733.

Dong, L., Pu, Y., Zhang, L., Qi, Q., Xu, L., Li, W., Wei, C., Wang, X., Zhou, S., Zhu, J. and Wang, X., 2018. Human umbilical cord mesenchymal stem cell-derived extracellular vesicles promote lung adenocarcinoma growth by transferring miR-410. Cell death \& disease, 9(2), p.218.

Dunn, L.J., Buhl, R., Lassen, C., Henley, M. and Kramer, B., 2010. Blinded 12-week comparison of once-daily indacaterol and tiotropium in COPD. CHEST Journal, 138(4_MeetingAbstracts), pp.719A-719A.

Dransfield, M.T., Bourbeau, J., Jones, P.W., Hanania, N.A., Mahler, D.A., Vestbo, J., Wachtel, A., Martinez, F.J., Barnhart, F., Sanford, L. and Lettis, S., 2013. Once-daily inhaled fluticasone furoate and vilanterol versus vilanterol only for prevention of exacerbations of COPD: two replicate double-blind, parallel-group, randomised controlled trials. The Lancet Respiratory Medicine, 1(3), pp.210-223.

Edwards, M.R., Bartlett, N.W., Clarke, D., Birrell, M., Belvisi, M. and Johnston, S.L., 2009. Targeting the NF-KB pathway in asthma and chronic obstructive pulmonary disease. Pharmacology \& therapeutics, 121(1), pp.1-13.

Ejiofor, Stan, and Alice M. Turner. "Pharmacotherapies for COPD." Clinical medicine insights. Circulatory, respiratory and pulmonary medicine 7 (2013): 17.

Fang, X., Abbott, J., Cheng, L., Colby, J.K., Lee, J.W., Levy, B.D. and Matthay, M.A., 2015. Human mesenchymal stem (Stromal) cells promote the resolution of acute lung injury in part. Issue: Journal of Immunology, 195 (3).

Ferrari, R., Tanni, S.E., Caram, L.M., Corrêa, C., Corrêa, C.R. and Godoy, I., 2013. Threeyear follow-up of Interleukin 6 and C-reactive protein in chronic obstructive pulmonary disease. Respiratory research, 14(1), p.24. 
Fresco, P., Borges, F., Diniz, C. and Marques, M.P.M., 2006. New insights on the anticancer properties of dietary polyphenols. Medicinal research reviews, 26(6), pp.747-766.

From the Global Strategy for the Diagnosis, Management and Prevention of COPD, Global Initiative for Chronic Obstructive Lung Disease (GOLD) 2017. Available from http://goldcopd.org

Fuhrmann-Stroissnigg, H., Ling, Y.Y., Zhao, J., McGowan, S.J., Zhu, Y., Brooks, R.W., Grassi, D., Gregg, S.Q., Stripay, J.L., Dorronsoro, A. and Corbo, L., 2017. Identification of HSP90 inhibitors as a novel class of senolytics. Nature Communications, 8.

Fukuchi, Y., 2009. The aging lung and chronic obstructive pulmonary disease: similarity and difference. Proceedings of the American Thoracic Society, 6(7), pp.570-572.

Furuya, N., Takenaga, M., Ohta, Y., Tokura, Y., Hamaguchi, A., Sakamaki, A., Kida, H., Handa, H., Nishine, H., Mineshita, M. and Miyazawa, T., 2012. Cell therapy with adipose tissue-derived stem/stromal cells for elastase-induced pulmonary emphysema in rats. Regenerative medicine, 7(4), pp.503-512.

Jurk, D. et al., 2014. Chronic inflammation induces telomere dysfunction and accelerates ageing in mice. Nature communications, 2(May), p.4172. Available at: http://www.ncbi.nlm.nih.gov/pubmed/24960204.

Stevenson, C.S. et al., 2007. Comprehensive gene expression profiling of rat lung reveals distinct acute and chronic responses to cigarette smoke inhalation. American journal of physiology. Lung cellular and molecular physiology, 293(5), pp.L1183-93. Available at: http://www.ncbi.nlm.nih.gov/pubmed/17720875.

Godtfredsen, N. S., et al. "Risk of hospital admission for COPD following smoking cessation and reduction: a Danish population study." Thorax 57.11 (2002): 967-972.

Grant, C.R., Liberal, R., Mieli-Vergani, G., Vergani, D. and Longhi, M.S., 2015. Regulatory Tcells in autoimmune diseases: challenges, controversies and-yet-unanswered questions. Autoimmunity reviews, 14(2), pp.105-116.

Grove, Daniel, Daniel J. Weiss, and Viranuj Sueblinvong. "Mesenchymal stem cells: promise for chronic obstructive pulmonary disease therapy?." Therapy 6.6 (2009): 779-782.

Hansen, M.J., Chan, S.P.J., Langenbach, S.Y., Dousha, L.F., Jones, J.E., Yatmaz, S., Seow, H.J., Vlahos, R., Anderson, G.P. and Bozinovski, S., 2014. IL-17A and serum amyloid A are elevated in a cigarette smoke cessation model associated with the persistence of pigmented macrophages, neutrophils and activated NK cells. PloS one, 9(11), p.e113180.

Hansmann, G., Fernandez-Gonzalez, A., Aslam, M., Vitali, S.H., Martin, T., Mitsialis, S.A. and Kourembanas, S., 2012. Mesenchymal stem cell-mediated reversal of bronchopulmonary dysplasia and associated pulmonary hypertension. Pulmonary circulation, 2(2), pp.170-181.

Hara, H., Araya, J., Ito, S., Kobayashi, K., Takasaka, N., Yoshii, Y., Wakui, H., Kojima, J., Shimizu, K., Numata, T. and Kawaishi, M., 2013. Mitochondrial fragmentation in cigarette smoke-induced bronchial epithelial cell senescence. American Journal of Physiology-Lung Cellular and Molecular Physiology, 305(10), pp.L737-L746.

Hara, H., Araya, J., Takasaka, N., Fujii, S., Kojima, J., Yumino, Y., Shimizu, K., Ishikawa, T., Numata, T., Kawaishi, M. and Saito, K., 2012. Involvement of creatine kinase b in cigarette smoke-induced bronchial epithelial cell senescence. American journal of respiratory cell and molecular biology, 46(3), pp.306-312. 
Hardie, J.A., Buist, A.S., Vollmer, W.M., Ellingsen, I., Bakke, P.S. and Mørkve, O., 2002. Risk of over-diagnosis of COPD in asymptomatic elderly never-smokers. European Respiratory Journal, 20(5), pp.1117-1122.

Hayflick, Leonard. "The limited in vitro lifetime of human diploid cell strains." Experimental cell research 37.3 (1965): 614-636.

Honczarenko, M., Le, Y.I., Swierkowski, M., Ghiran, I., Glodek, A.M. and Silberstein, L.E., 2006. Human bone marrow stromal cells express a distinct set of biologically functional chemokine receptors. Stem cells, 24(4), pp.1030-1041.

Huang, J., Yin, S.J., Chen, Y.J., Bian, W.H., Yu, J., Zhao, Y.W. and Liu, X.Y., 2010. Transplanted bone marrow stromal cells improve cognitive dysfunction due to aging hypoperfusion in rats. Chinese medical journal, 123(24), pp.3620-3625.

Goldstein, R.H., Reagan, M.R., Anderson, K., Kaplan, D.L. and Rosenblatt, M., 2010. Human bone marrow-derived MSCs can home to orthotopic breast cancer tumors and promote bone metastasis. Cancer research, 70(24), pp.10044-10050.

Ikeno, Y., Orihuela, C. and Van Remmen, H., 2011. Inflammation in Aging and Age-related Disease. Pathobiology of Aging \& Age-related Diseases, 1(1), p.14729.

Isajevs, S., Taivans, I., Svirina, D., Strazda, G. and Kopeika, U., 2011. Patterns of inflammatory responses in large and small airways in smokers with and without chronic obstructive pulmonary disease. Respiration, 81(5), pp.362-371.

Jarvinen, L., Badri, L., Wettlaufer, S., Ohtsuka, T., Standiford, T.J., Toews, G.B., Pinsky, D.J., Peters-Golden, M. and Lama, V.N., 2008. Lung resident mesenchymal stem cells isolated from human lung allografts inhibit $\mathrm{T}$ cell proliferation via a soluble mediator. The Journal of Immunology, 181(6), pp.4389-4396.

John, G., Kohse, K., Orasche, J., Reda, A., Schnelle-Kreis, J., Zimmermann, R., Schmid, O., Eickelberg, O. and Yildirim, A.Ö., 2014. The composition of cigarette smoke determines inflammatory cell recruitment to the lung in COPD mouse models. Clinical science, 126(3), pp.207-221.

Jurk, D., Wilson, C., Passos, J.F., Oakley, F., Correia-Melo, C., Greaves, L., Saretzki, G., Fox, C., Lawless, C., Anderson, R. and Hewitt, G., 2014. Chronic inflammation induces telomere dysfunction and accelerates ageing in mice. Nature communications, 5.

Kanaji, N., Basma, H., Nelson, A., Farid, M., Sato, T., Nakanishi, M., Wang, X., Michalski, J., $\mathrm{Li}$, Y., Gunji, Y. and Feghali-Bostwick, C., 2014. Fibroblasts that resist cigarette smokeinduced senescence acquire profibrotic phenotypes. American Journal of Physiology-Lung Cellular and Molecular Physiology, 307(5), pp.L364-L373.

Kanner, Richard E., et al. "Effects of randomized assignment to a smoking cessation intervention and changes in smoking habits on respiratory symptoms in smokers with early chronic obstructive pulmonary disease: the Lung Health Study." The American journal of medicine 106.4 (1999): 410-416.

Karrasch, S., Holz, O. and Jörres, R.A., 2008. Aging and induced senescence as factors in the pathogenesis of lung emphysema. Respiratory medicine, 102(9), pp.1215-1230.

Keatings, V.M., Jatakanon, A., Worsdell, Y.M. and Barnes, P.J., 1997. Effects of inhaled and oral glucocorticoids on inflammatory indices in asthma and COPD. American journal of respiratory and critical care medicine, 155(2), pp.542-548. 
Kesten, S., Jara, M., Wentworth, C. and Lanes, S., 2006. Pooled clinical trial analysis of tiotropium safety. CHEST Journal, 130(6), pp.1695-1703.

Khatri, M., Richardson, L.A. and Meulia, T., 2018. Mesenchymal stem cell-derived extracellular vesicles attenuate influenza virus-induced acute lung injury in a pig model. Stem cell research \& therapy, 9(1), p.17.

Kim, C.F.B., Jackson, E.L., Woolfenden, A.E., Lawrence, S., Babar, I., Vogel, S., Crowley, D., Bronson, R.T. and Jacks, T., 2005. Identification of bronchioalveolar stem cells in normal lung and lung cancer. Cell, 121(6), pp.823-835.

Kim, K.S., Kang, K.W., Seu, Y.B., Baek, S.H. and Kim, J.R., 2009. Interferon-y induces cellular senescence through p53-dependent DNA damage signaling in human endothelial cells. Mechanisms of ageing and development, 130(3), pp.179-188.

Kirkland, J.L., Tchkonia, T., Zhu, Y., Niedernhofer, L.J. and Robbins, P.D., 2017. The Clinical Potential of Senolytic Drugs. Journal of the American Geriatrics Society.

Krtolica, A., Parrinello, S., Lockett, S., Desprez, P.Y. and Campisi, J., 2001. Senescent fibroblasts promote epithelial cell growth and tumorigenesis: a link between cancer and aging. Proceedings of the National Academy of Sciences, 98(21), pp.12072-12077.

Lalu, M.M., McIntyre, L., Pugliese, C., Fergusson, D., Winston, B.W., Marshall, J.C., Granton, J. and Stewart, D.J., 2012. Safety of cell therapy with mesenchymal stromal cells (SafeCell): a systematic review and meta-analysis of clinical trials. PloS one, 7(10), p.e47559.

Lapperre, T.S., Postma, D.S., Gosman, M.M., Snoeck-Stroband, J.B., ten Hacken, N.H., Hiemstra, P.S., Timens, W., Sterk, P.J. and Mauad, T., 2006. Relation between duration of smoking cessation and bronchial inflammation in COPD. Airway pathology in COPD: smoking cessation and pharmacological treatment intervention, 61(2), p.73.

Lee, B.Y., Han, J.A., Im, J.S., Morrone, A., Johung, K., Goodwin, E.C., Kleijer, W.J., DiMaio, D. and Hwang, E.S., 2006. Senescence-associated $\beta$-galactosidase is lysosomal $\beta$-galactosidase. Aging cell, 5(2), pp.187-195.

Lee, C., Mitsialis, S.A., Aslam, M., Vitali, S.H., Vergadi, E., Konstantinou, G., Sdrimas, K., Fernandez-gonzalez, A. and Kourembanas, S., 2012. Exosomes mediate the cytoprotective action of mesenchymal stromal cells on hypoxia-induced pulmonary hypertension. Circulation, 126(22), pp.2601-2611.

Lee, J.W., Fang, X., Gupta, N., Serikov, V. and Matthay, M.A., 2009. Allogeneic human mesenchymal stem cells for treatment of $E$. coli endotoxin-induced acute lung injury in the ex vivo perfused human lung. Proceedings of the National Academy of Sciences, 106(38), pp.16357-16362.

Lee, M., Jeong, S.Y., Ha, J., Kim, M., Jin, H.J., Kwon, S.J., Chang, J.W., Choi, S.J., Oh, W., Yang, Y.S. and Kim, J.S., 2014. Low immunogenicity of allogeneic human umbilical cord blood-derived mesenchymal stem cells in vitro and in vivo. Biochemical and Biophysical Research Communications, 446(4), pp.983-989.

Lee, S.H., Goswami, S., Grudo, A., Li-zhen, S., Bandi, V., Goodnight-White, S., Green, L., Hacken-Bitar, J., Huh, J., Bakaeen, F. and Coxson, H.O., 2007. Antielastin autoimmunity in tobacco smoking-induced emphysema. Nature medicine, 13(5), p.567.

Lehmann, M., Korfei, M., Mutze, K., Klee, S., Skronska-Wasek, W., Alsafadi, H.N., Ota, C., Costa, R., Schiller, H.B., Lindner, M. and Wagner, D.E., 2017. Senolytic drugs target alveolar 
epithelial cell function and attenuate experimental lung fibrosis ex vivo. European Respiratory Journal, 50(2), p.1602367.

Li, H., Fan, X., Kovi, R.C., Jo, Y., Moquin, B., Konz, R., Stoicov, C., Kurt-Jones, E., Grossman, S.R., Lyle, S. and Rogers, A.B., 2007. Spontaneous expression of embryonic factors and p53 point mutations in aged mesenchymal stem cells: a model of age-related tumorigenesis in mice. Cancer research, 67(22), pp.10889-10898.

Li, J., Li, D., Liu, X., Tang, S. and Wei, F., 2012. Human umbilical cord mesenchymal stem cells reduce systemic inflammation and attenuate LPS-induced acute lung injury in rats. Journal of Inflammation, 9(1), p.33.

Li, W., Ren, G., Huang, Y., Su, J., Han, Y., Li, J., Chen, X., Cao, K., Chen, Q., Shou, P. and Zhang, L., 2012. Mesenchymal stem cells: a double-edged sword in regulating immune responses. Cell Death \& Differentiation, 19(9), pp.1505-1513.

Lin, S.Y., Dolfi, S.C., Amiri, S., Li, J., Budak-Alpdogan, T., Lee, K.C., Derenzo, C., Banerjee, D. and Glod, J., 2013. P53 regulates the migration of mesenchymal stromal cells in response to the tumor microenvironment through both CXCL12-dependent and-independent mechanisms. International journal of oncology, 43(6), pp.1817-1823.

Lipworth, B.J., Clark, R.A., Dhillon, D.P. and McDevitt, D.G., 1990. Comparison of the effects of prolonged treatment with low and high doses of inhaled terbutaline on beta-adrenoceptor responsiveness in patients with chronic obstructive pulmonary disease. Am Rev Respir Dis, 142(2), pp.338-342.

Liu, L., Chiu, P.W.Y., Lam, P.K., Poon, C.C.Y., Lam, C.C.H., Ng, E.K.W. and Lai, P.B.S., 2015. Effect of local injection of mesenchymal stem cells on healing of sutured gastric perforation in an experimental model. British Journal of Surgery, 102(2).

Liu, L., Yu, Y., Hou, Y., Chai, J., Duan, H., Chu, W., Zhang, H., Hu, Q. and Du, J., 2014. Human umbilical cord mesenchymal stem cells transplantation promotes cutaneous wound healing of severe burned rats. PloS one, 9(2), p.e88348.

Liu, Q., Luo, Z., He, S., Peng, X., Xiong, S., Wang, Y., Zhong, X., Zhou, X., Eisenberg, C.A. and Gao, B.Z., 2013. Conditioned serum-free medium from umbilical cord mesenchymal stem cells has anti-photoaging properties. Biotechnology letters, 35(10), pp.1707-1714.

Liu, T., Zhu, K., Ke, C., Yang, S., Yang, F., Li, Z. and Zhang, Z., 2017. Mesenchymal stem cells inhibited development of lung cancer induced by chemical carcinogens in a rat model. American journal of translational research, 9(6), p.2891.

Liu, X., Fang, Q. and Kim, H., 2016. Preclinical Studies of Mesenchymal Stem Cell (MSC) Administration in Chronic Obstructive Pulmonary Disease (COPD): A Systematic Review and Meta-Analysis. PloS one, 11(6), p.e0157099.

Loke, Y.K., Cavallazzi, R. and Singh, S., 2011. Risk of fractures with inhaled corticosteroids in COPD: systematic review and meta-analysis of randomised controlled trials and observational studies. Thorax, 66(8), pp.699-708.

Lourenco, S., Teixeira, V.H., Kalber, T., Jose, R.J., Floto, R.A. and Janes, S.M., 2015. Macrophage migration inhibitory factor-CXCR4 is the dominant chemotactic axis in human mesenchymal stem cell recruitment to tumors. The Journal of Immunology, 194(7), pp.34633474. 
Lu, Y.R., Yuan, Y., Wang, X.J., Wei, L.L., Chen, Y.N., Cong, C., Li, S.F., Long, D., Tan, W.D., Mao, Y.Q. and Zhang, J., 2008. The growth inhibitory effect of mesenchymal stem cells on tumor cells in vitro and in vivo. Cancer biology \& therapy, 7(2), pp.245-251.

Ludwig, A. K., \& Giebel, B. (2012). Exosomes: small vesicles participating in intercellular communication. The international journal of biochemistry \& cell biology, 44(1), 11-15.

Lujambio, A., 2016. To clear, or not to clear (senescent cells)? That is the question. Bioessays, 38(S1), pp.S56-S64.

Maltais, François, et al. "Aclidinium bromide improves exercise endurance and lung hyperinflation in patients with moderate to severe COPD." Respiratory medicine 105.4 (2011): 580-587.

Marwick, J.A., Kirkham, P.A., Stevenson, C.S., Danahay, H., Giddings, J., Butler, K., Donaldson, K., MacNee, W. and Rahman, I., 2004. Cigarette smoke alters chromatin remodeling and induces proinflammatory genes in rat lungs. American journal of respiratory cell and molecular biology, 31(6), pp.633-642.

Marwick, J.A., Stevenson, C.S., Giddings, J., MacNee, W., Butler, K., Rahman, I. and Kirkham, P.A., 2006. Cigarette smoke disrupts VEGF165-VEGFR-2 receptor signaling complex in rat lungs and patients with COPD: morphological impact of VEGFR-2 inhibition. American Journal of Physiology-Lung Cellular and Molecular Physiology, 290(5), pp.L897-L908.

Massberg, S., Konrad, I., Schürzinger, K., Lorenz, M., Schneider, S., Zohlnhoefer, D., Hoppe, K., Schiemann, M., Kennerknecht, E., Sauer, S. and Schulz, C., 2006. Platelets secrete stromal cell-derived factor $1 \alpha$ and recruit bone marrow-derived progenitor cells to arterial thrombi in vivo. Journal of Experimental Medicine, 203(5), pp.1221-1233.

Majo, J., Ghezzo, H. and Cosio, M.G., 2001. Lymphocyte population and apoptosis in the lungs of smokers and their relation to emphysema. European Respiratory Journal, 17(5), pp.946-953.

Mathias, L.J., Khong, S.M., Spyroglou, L., Payne, N.L., Siatskas, C., Thorburn, A.N., Boyd, R.L. and Heng, T.S., 2013. Alveolar macrophages are critical for the inhibition of allergic asthma by mesenchymal stromal cells. The Journal of Immunology, 191(12), pp.5914-5924.

Mei, S.H., Haitsma, J.J., Dos Santos, C.C., Deng, Y., Lai, P.F., Slutsky, A.S., Liles, W.C. and Stewart, D.J., 2010. Mesenchymal stem cells reduce inflammation while enhancing bacterial clearance and improving survival in sepsis. American journal of respiratory and critical care medicine, 182(8), pp.1047-1057.

Mei, S.H., McCarter, S.D., Deng, Y., Parker, C.H., Liles, W.C. and Stewart, D.J., 2007. Prevention of LPS-induced acute lung injury in mice by mesenchymal stem cells overexpressing angiopoietin 1. PLoS medicine, 4(9), p.e269.

Moodley, Y., Atienza, D., Manuelpillai, U., Samuel, C.S., Tchongue, J., Ilancheran, S., Boyd, R. and Trounson, A., 2009. Human umbilical cord mesenchymal stem cells reduce fibrosis of bleomycin-induced lung injury. The American journal of pathology, 175(1), pp.303-313.

Mortaz, E., Henricks, P.A.J., Kraneveld, A.D., Givi, M.E., Garssen, J. and Folkerts, G., 2011. Cigarette smoke induces the release of $\mathrm{CXCL}-8$ from human bronchial epithelial cells via 
TLRs and induction of the inflammasome. Biochimica et Biophysica Acta (BBA)-Molecular Basis of Disease, 1812(9), pp.1104-1110.

Mousavinejad, M., Andrews, P.W. and Shoraki, E.K., 2016. Current biosafety considerations in stem cell therapy. Cell Journal (Yakhteh), 18(2), p.281.

Nannini, Luis Javier, et al. "Combined corticosteroid and long-acting beta-agonist in one inhaler versus placebo for chronic obstructive pulmonary disease." The Cochrane Library (2007).

Neckers, L. and Workman, P., 2012. Hsp90 molecular chaperone inhibitors: are we there yet? Clinical cancer research, 18(1), pp.64-76.

Niu, G., Li, Z., Cao, Q. and Chen, X., 2009. Monitoring therapeutic response of human ovarian cancer to 17-DMAG by noninvasive PET imaging with 64Cu-DOTAtrastuzumab. European journal of nuclear medicine and molecular imaging, 36(9), p.1510.

Oliveira, R.L., Chagastelles, P.C., Sesterheim, P. and Pranke, P., 2017. In Vivo Immunogenic Response to Allogeneic Mesenchymal Stem Cells and the Role of Preactivated Mesenchymal Stem Cells Cotransplanted with Allogeneic Islets. Stem cells international, 2017.Pauwels, R.A., Löfdahl, C.G., Laitinen, L.A., Schouten, J.P., Postma, D.S., Pride, N.B. and Ohlsson, S.V., 1999. Long-term treatment with inhaled budesonide in persons with mild chronic obstructive pulmonary disease who continue smoking. New England Journal of Medicine, 340(25), pp.1948-1953.

Peron, J.P.S., de Brito, A.A., Pelatti, M., Brandão, W.N., Vitoretti, L.B., Greiffo, F.R., da Silveira, E.C., Oliveira-Junior, M.C., Maluf, M., Evangelista, L. and Halpern, S., 2015. Human Tubal-Derived Mesenchymal Stromal Cells Associated with Low Level Laser Therapy Significantly Reduces Cigarette Smoke-Induced COPD in C57BL/6 mice. PloS one, 10(8), p.e0136942.

Pittenger, M.F., A.M. Mackay, S.C. Beck, R.K. Jaiswal, R. Douglas, J.D. Mosca, M.A. Moorman, D.W. Simonetti, S. Craig, and D.R. Marshak. 1999. Multilineage potential of adult human mesenchymal stem cells. science 284:143-147

Quint, J.K. and Wedzicha, J.A., 2007. The neutrophil in chronic obstructive pulmonary disease. Journal of Allergy and Clinical Immunology, 119(5), pp.1065-1071.

Rajendrasozhan, S., Yang, S.R., Kinnula, V.L. and Rahman, I., 2008. SIRT1, an antiinflammatory and antiaging protein, is decreased in lungs of patients with chronic obstructive pulmonary disease. American journal of respiratory and critical care medicine, 177(8), pp.861-870.

Rasmusson, I., O. RingdÃ@n, B. Sundberg, and K. Le Blanc. 2003. Mesenchymal stem cells inhibit the formation of cytotoxic $T$ lymphocytes, but not activated cytotoxic $T$ lymphocytes or natural killer cells. Transplantation 76:1208-1213

Ribeiro-Paes, J.T., Bilaqui, A., Greco, O.T., Ruiz, M.A., Marcelino, M.Y., Stessuk, T., de Faria, C.A. and Lago, M.R., 2011. Unicentric study of cell therapy in chronic obstructive pulmonary disease/pulmonary emphysema. International journal of chronic obstructive pulmonary disease, 6, p.63.

Ries, C., Egea, V., Karow, M., Kolb, H., Jochum, M. and Neth, P., 2007. MMP-2, MT1-MMP, and TIMP-2 are essential for the invasive capacity of human mesenchymal stem cells: differential regulation by inflammatory cytokines. Blood, 109(9), pp.4055-4063.

Ringe, J., Strassburg, S., Neumann, K., Endres, M., Notter, M., Burmester, G.R., Kaps, C. and Sittinger, M., 2007. Towards in situ tissue repair: human mesenchymal stem cells 
express chemokine receptors CXCR1, CXCR2 and CCR2, and migrate upon stimulation with CXCL8 but not CCL2. Journal of cellular biochemistry, 101(1), pp.135-146.

Roos, C.M., Zhang, B., Palmer, A.K., Ogrodnik, M.B., Pirtskhalava, T., Thalji, N.M., Hagler, M., Jurk, D., Smith, L.A., Casaclang-Verzosa, G. and Zhu, Y., 2016. Chronic senolytic treatment alleviates established vasomotor dysfunction in aged or atherosclerotic mice. Aging Cell, 15(5), pp.973-977.

Ross, H.H., Levkoff, L.H., Marshall, G.P., Caldeira, M., Steindler, D.A., Reynolds, B.A. and Laywell, E.D., 2008. Bromodeoxyuridine induces senescence in neural stem and progenitor cells. Stem cells, 26(12), pp.3218-3227.

Rudin, C.M., Hann, C.L., Garon, E.B., De Oliveira, M.R., Bonomi, P.D., Camidge, D.R., Chu, Q., Giaccone, G., Khaira, D., Ramalingam, S.S. and Ranson, M.R., 2012. Phase II study of single-agent navitoclax (ABT-263) and biomarker correlates in patients with relapsed small cell lung cancer. Clinical Cancer Research, 18(11), pp.3163-3169.

Sato, Kazuya, et al. "Nitric oxide plays a critical role in suppression of T-cell proliferation by mesenchymal stem cells." Blood 109.1 (2007): 228-234.

Serasanambati, M. and Chilakapati, S.R., 2016. Function of nuclear factor kappa B (NF-kB) in human diseases-a review. South Indian Journal of Biological Sciences, 2(4), pp.368-387.

Serrano, M., Lin, A.W., McCurrach, M.E., Beach, D. and Lowe, S.W., 1997. Oncogenic ras provokes premature cell senescence associated with accumulation of p53 and p16 INK4a. Cell, 88(5), pp.593-602.

Shapiro, S. D. (1999). The macrophage in chronic obstructive pulmonary disease. American journal of respiratory and critical care medicine, 160(supplement_1), S29-S32.

Shen, X.H., Xu, S.J., Jin, C.Y., Ding, F., Zhou, Y.C. and Fu, G.S., 2013. Interleukin-8 prevents oxidative stress-induced human endothelial cell senescence via telomerase activation. International immunopharmacology, 16(2), pp.261-267.

Shigemura, N., Sawa, Y., Mizuno, S., Ono, M., Ohta, M., Nakamura, T., Kaneda, Y. and Matsuda, H., 2005. Amelioration of pulmonary emphysema by in vivo gene transfection with hepatocyte growth factor in rats. Circulation, 111(11), pp.1407-1414.

Singh, S., Loke, Y.K. and Furberg, C.D., 2008. Inhaled anticholinergics and risk of major adverse cardiovascular events in patients with chronic obstructive pulmonary disease: a systematic review and meta-analysis. Jama, 300(12), pp.1439-1450.

Soler-Cataluna, J.J., Cosío, B., Izquierdo, J.L., López-Campos, J.L., Marín, J.M., Agüero, R., Baloira, A., Carrizo, S., Esteban, C., Galdiz, J.B. and González, M.C., 2012. Consensus document on the overlap phenotype COPD-asthma in COPD. Archivos de Bronconeumología (English Edition), 48(9), pp.331-337.

Stessuk, T., Ruiz, M.A., Greco, O.T., Bilaqui, A., Ribeiro-Paes, M.J.D.O. and Ribeiro-Paes, J.T., 2013. Phase I clinical trial of cell therapy in patients with advanced chronic obstructive pulmonary disease: follow-up of up to 3 years. Revista brasileira de hematologia $e$ hemoterapia, 35(5), pp.352-357.

Stevenson, C.S., Docx, C., Webster, R., Battram, C., Hynx, D., Giddings, J., Cooper, P.R., Chakravarty, P., Rahman, I., Marwick, J.A. and Kirkham, P.A., 2007. Comprehensive gene expression profiling of rat lung reveals distinct acute and chronic responses to cigarette smoke inhalation. American Journal of Physiology-Lung Cellular and Molecular Physiology, 293(5), pp. L1183-L1193. 
Stolk, J., Broekman, W., Mauad, T., Zwaginga, J.J., Roelofs, H., Fibbe, W.E., Oostendorp, J., Bajema, I., Versteegh, M.I.M., Taube, C. and Hiemstra, P.S., 2016. A phase I study for intravenous autologous mesenchymal stromal cell administration to patients with severe emphysema. QJM: An International Journal of Medicine, 109(5), pp.331-336.

Strojny, C., Boyle, M., Bartholomew, A., Sundivakkam, P. and Alapati, S., 2015. Interferon gamma-treated dental pulp stem cells promote human mesenchymal stem cell migration in vitro. Journal of endodontics, 41(8), pp.1259-1264.

Suissa, S., Patenaude, V., Lapi, F. and Ernst, P., 2013. Inhaled corticosteroids in COPD and the risk of serious pneumonia. Thorax, 68(11), pp.1029-1036.

Sun, Y., Hu, X., Hu, G., Xu, C. and Jiang, H., 2015. Curcumin attenuates hydrogen peroxideinduced premature senescence via the activation of SIRT1 in human umbilical vein endothelial cells. Biological and Pharmaceutical Bulletin, 38(8), pp.1134-1141.

Tabera, S., Pérez-Simón, J.A., Díez-Campelo, M., Sánchez-Abarca, L.l., Blanco, B., López, A., Benito, A., Ocio, E., Sánchez-Guijo, F.M., Cañizo, C. and San Miguel, J.F., 2008. The effect of mesenchymal stem cells on the viability, proliferation and differentiation of Blymphocytes. haematologica, 93(9), pp.1301-1309.

Takeda, K., Webb, T., Ning, F., Shiraishi, Y., Regan, D., Chow, K., Smith, M., Ashino, S., Guth, A., Dow, S. and Gelfnad, E.W., 2017. Mesenchymal Stem Cells Recruit IL-10Producing Monocytes And Macrophages Through Activation Of The CCL2-CCR2 Axis To Suppress Allergic Airway Inflammation. In D12. MECHANISMS OF ALLERGIC AIRWAY INFLAMMATION (pp. A6995-A6995). American Thoracic Society.

Tashkin, D.P., Celli, B., Senn, S., Burkhart, D., Kesten, S., Menjoge, S. and Decramer, M., 2008. A 4-year trial of tiotropium in chronic obstructive pulmonary disease. New England Journal of Medicine, 359(15), pp.1543-1554.

Thomson, N.C., Angus, R., Quebe-Fehling, E. and Brambilla, R., 1998. Efficacy and tolerability of formoterol in elderly patients with reversible obstructive airways disease. Respiratory medicine, 92(3), pp.562-567.

Tilstra, J.S., Robinson, A.R., Wang, J., Gregg, S.Q., Clauson, C.L., Reay, D.P., Nasto, L.A., St Croix, C.M., Usas, A., Vo, N. and Huard, J., 2012. NF-kB inhibition delays DNA damageinduced senescence and aging in mice. The Journal of clinical investigation, 122(7), p.2601.

Tofiño-Vian, M., Guillén, M.I., del Caz, P., Dolores, M., Castejón, M.A. and Alcaraz, M.J., 2017. Extracellular vesicles from adipose-derived mesenchymal stem cells downregulate senescence features in osteoarthritic osteoblasts. Oxidative medicine and cellular longevity, 2017.

Tropea, K.A., Leder, E., Aslam, M., Lau, A.N., Raiser, D.M., Lee, J.H., Balasubramaniam, V., Fredenburgh, L.E., Mitsialis, S.A., Kourembanas, S. and Kim, C.F., 2012. Bronchioalveolar stem cells increase after mesenchymal stromal cell treatment in a mouse model of bronchopulmonary dysplasia. American Journal of Physiology-Lung Cellular and Molecular Physiology, 302(9), pp.L829-L837.

Tse, W.T., J.D. Pendleton, W.M. Beyer, M.C. Egalka, and E.C. Guinan. 2003. Suppression of allogeneic T-cell proliferation by human marrow stromal cells: implications in transplantation. TRANSPLANTATION-BALTIMORE- 75:389-397.

Tsoumakidou, M., Demedts, I.K., Brusselle, G.G. and Jeffery, P.K., 2008. Dendritic cells in chronic obstructive pulmonary disease: new players in an old game. American journal of respiratory and critical care medicine, 177(11), pp.1180-1186. 
Tsuji, T., Aoshiba, K. and Nagai, A., 2006. Alveolar cell senescence in patients with pulmonary emphysema. American journal of respiratory and critical care medicine, 174(8), pp.886-893.

Tsuji, T., Aoshiba, K. and Nagai, A., 2010. Alveolar cell senescence exacerbates pulmonary inflammation in patients with chronic obstructive pulmonary disease. Respiration, 80(1), pp.59-70.

Tsushima, K., King, L.S., Aggarwal, N.R., De Gorordo, A., D'Alessio, F.R. and Kubo, K., 2009. Acute lung injury review. Internal medicine, 48(9), pp.621-630.

van Haaften, T., Byrne, R., Bonnet, S., Rochefort, G.Y., Akabutu, J., Bouchentouf, M., ReyParra, G.J., Galipeau, J., Haromy, A., Eaton, F. and Chen, M., 2009. Airway delivery of mesenchymal stem cells prevents arrested alveolar growth in neonatal lung injury in rats. American journal of respiratory and critical care medicine, 180(11), pp.1131-1142.

van Rijt, L.S., Vos, N., Willart, M., KleinJan, A., Coyle, A.J., Hoogsteden, H.C. and Lambrecht, B.N., 2004. Essential role of dendritic cell CD80/CD86 costimulation in the induction, but not reactivation, of $\mathrm{T} \mathrm{H} 2$ effector responses in a mouse model of asthma. Journal of Allergy and Clinical Immunology, 114(1), pp.166-173.

Vasandan, A.B., Jahnavi, S., Shashank, C., Prasad, P., Kumar, A. and Prasanna, S.J., 2016. Human Mesenchymal stem cells program macrophage plasticity by altering their metabolic status via a PGE2-dependent mechanism. Scientific reports, 6.

Ventura, A., Kirsch, D.G., McLaughlin, M.E., Tuveson, D.A., Grimm, J., Lintault, L., Newman, J., Reczek, E.E., Weissleder, R. and Jacks, T., 2007. Restoration of p53 function leads to tumour regression in vivo. Nature, 445(7128), pp.661-665.

Vincken, W., et al. "Improved health outcomes in patients with COPD during 1 year's treatment with tiotropium." European Respiratory Journal 19.2 (2002): 209-216.

Wagner, W., Horn, P., Castoldi, M., Diehlmann, A., Bork, S., Saffrich, R., Benes, V., Blake, J., Pfister, S., Eckstein, V. and Ho, A.D., 2008. Replicative senescence of mesenchymal stem cells: a continuous and organized process. PloS one, 3(5), p.e2213.

Waldman, T., Kinzler, K.W. and Vogelstein, B., 1995. p21 is necessary for the p53-mediated G1 arrest in human cancer cells. Cancer research, 55(22), pp.5187-5190.

Weiss, D.J., Casaburi, R., Flannery, R., LeRoux-Williams, M. and Tashkin, D.P., 2013. A placebo-controlled, randomized trial of mesenchymal stem cells in COPD. CHEST Journal, 143(6), pp.1590-1598.

Wu, J., Ji, C., Cao, F., Lui, H., Xia, B. and Wang, L., 2017. Bone marrow mesenchymal stem cells inhibit dendritic cells differentiation and maturation by microRNA-23b. Bioscience reports, 37(2), p.BSR20160436.

Xie, C., Jin, J., Lv, X., Tao, J., Wang, R. and Miao, D., 2015. Anti-aging effect of transplanted amniotic membrane mesenchymal stem cells in a premature aging model of Bmi-1 deficiency. Scientific reports, 5, p.srep13975.

Xu, M., Tchkonia, T., Ding, H., Ogrodnik, M., Lubbers, E.R., Pirtskhalava, T., White, T.A., Johnson, K.O., Stout, M.B., Mezera, V. and Giorgadze, N., 2015. JAK inhibition alleviates the cellular senescence-associated secretory phenotype and frailty in old age. Proceedings of the National Academy of Sciences, 112(46), pp.E6301-E6310. 
Yamagata, K., Suzuki, S. and Tagami, M., 2016. Docosahexaenoic acid prevented tumor necrosis factor alpha-induced endothelial dysfunction and senescence. Prostaglandins, Leukotrienes and Essential Fatty Acids (PLEFA), 104, pp.11-18.

Yamaza, T., Miura, Y., Akiyama, K., Bi, Y., Sonoyama, W., Gronthos, S., Chen, W., Le, A. and Shi, S., 2009. Mesenchymal stem cell-mediated ectopic hematopoiesis alleviates agingrelated phenotype in immunocompromised mice. Blood, 113(11), pp.2595-2604.

Yao, H., Chung, S., Hwang, J.W., Rajendrasozhan, S., Sundar, I.K., Dean, D.A., McBurney, M.W., Guarente, L., Gu, W., Rönty, M. and Kinnula, V.L., 2012. SIRT1 protects against emphysema via FOXO3-mediated reduction of premature senescence in mice. The Journal of clinical investigation, 122(6), p.2032.

Yeh, S.P., Lo, W.J. and Chiu, C.F., 2011. Bone Marrow-Derived Mesenchymal Stem Cell Homing to Breast Cancer but Not Colon and Renal Cancer and VEGF-C and VEGF-R3 Play the Key Role in Tumor Homing Effect in the Syngeneic Mice (Balb/c) Model.

Yu, B., Zhang, X., \& Li, X. (2014). Exosomes derived from mesenchymal stem cells. International journal of molecular sciences, 15(3), 4142-4157.

Zeng, S.L., Wang, L.H., Li, P., Wang, W. and Yang, J., 2015. Mesenchymal stem cells abrogate experimental asthma by altering dendritic cell function. Molecular medicine reports, 12(2), pp.2511-2520.

Zhang, Mingyu, et al. "Bone marrow mesenchymal stem cell transplantation retards the natural senescence of rat hearts." Stem cells translational medicine 4.5 (2015): 494-502.

Zhang, Z., Yang, J., Yan, W., Li, Y., Shen, Z. and Asahara, T., 2016. Pretreatment of cardiac stem cells with exosomes derived from mesenchymal stem cells enhances myocardial repair. Journal of the American Heart Association, 5(1), p.e002856.

Zhao, W., Wang, C., Liu, R., Wei, C., Duan, J., Liu, K., Li, S., Zou, H., Zhao, J., Wang, L. and Qi, Y., 2016. Effect of TGF- $\beta 1$ on the migration and recruitment of mesenchymal stem cells after vascular balloon injury: involvement of matrix metalloproteinase-14. Scientific reports, 6 .

Zhu, Y., Doornebal, E.J., Pirtskhalava, T., Giorgadze, N., Wentworth, M., FuhrmannStroissnigg, H., Niedernhofer, L.J., Robbins, P.D., Tchkonia, T. and Kirkland, J.L., 2017. New agents that target senescent cells: the flavone, fisetin, and the BCL-XL inhibitors, A1331852 and A1155463. Aging (Albany NY), 9(3), p.955.

Zhu, Y., Tchkonia, T., Fuhrmann-Stroissnigg, H., Dai, H.M., Ling, Y.Y., Stout, M.B., Pirtskhalava, T., Giorgadze, N., Johnson, K.O., Giles, C.B. and Wren, J.D., 2016. Identification of a novel senolytic agent, navitoclax, targeting the Bcl-2 family of anti-apoptotic factors. Aging Cell, 15(3), pp.428-435.

Zhu, Y., Tchkonia, T., Pirtskhalava, T., Gower, A.C., Ding, H., Giorgadze, N., Palmer, A.K., Ikeno, Y., Hubbard, G.B., Lenburg, M. and O'hara, S.P., 2015. The Achilles' heel of senescent cells: from transcriptome to senolytic drugs. Aging cell, 14(4), pp.644-658.

Zhu, Y.G., Feng, X.M., Abbott, J., Fang, X.H., Hao, Q., Monsel, A., Qu, J.M., Matthay, M.A. and Lee, J.W., 2014. Human mesenchymal stem cell microvesicles for treatment of Escherichia coli endotoxin-induced acute lung injury in mice. Stem cells, 32(1), pp.116-125.

Zuo, L., He, F., Sergakis, G.G., Koozehchian, M.S., Stimpfl, J.N., Rong, Y., Diaz, P.T. and Best, T.M., 2014. Interrelated role of cigarette smoking, oxidative stress, and immune 
response in COPD and corresponding treatments. American Journal of Physiology-Lung Cellular and Molecular Physiology, 307(3), pp.L205-L218. 